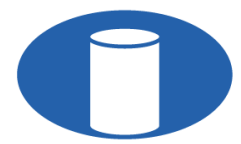

IBRACON Structures and Materials Journal

Revista IBRACON de Estruturas e Materiais

IBRACON

ISSN 1983-4195

ismj.org

ORIGINAL ARTICLE

\title{
Alkali-silica reaction (ASR) - Investigation of crystallographic parameters of natural sands by backscattered electron diffraction
}

\author{
Reação álcali-sílica (RAS) - Investigação de parâmetros cristalográficos de areias \\ naturais, por difração de elétrons retroespalhados
}

Kleber Franke Portella ${ }^{\mathrm{a}}$

Leonardo Evangelista Lagoeiro ${ }^{\mathrm{b}}$ (it)

Jeferson Luiz Bronholo ${ }^{\text {a }}$ (D)

Dayane de Cristo Miranda ${ }^{a}$

Mariana D’Orey Gaivão Portella Bragança ${ }^{a}$ (D)

Bruna Gomes Dias ${ }^{\mathrm{a}}$ (D)

Nicole Pagan Hasparyk ${ }^{c}$ (D)

Selmo Chapira Kuperman ${ }^{\mathrm{d}}$

${ }^{a}$ LACTEC, Estruturas Civis, Curitiba, PR, Brasil

bUniversidade Federal do Paraná - UFPR, Departamento de Geologia, Curitiba, PR, Brasil

${ }^{\mathrm{c}}$ FURNAS Centrais Elétricas S. A., Gerência de Serviços e Suporte Tecnológico, Goiânia, GO, Brasil

${ }^{\mathrm{d} D E S E K}$, São Paulo, SP, Brasil

Received 02 June 2020

Accepted 13 August 2020

\begin{abstract}
This study involved analyzing several natural sands to ascertain the possible causes for distress due to ASR. The analyses were performed using the following techniques: X-ray diffractometry, accelerated mortar bar tests (AMBT), electron backscattering diffraction and elementary chemistry analyses, by FEGSEM/EBSD/EDS. These experiments allowed identifying the presence of several mineral composites (such as microcline, anorthite, among others), as well as the microstructural-crystallographic planes of quartz (such as the Dauphiné type). From the results it could be inferred that the multiple techniques used, especially the FEG-SEM / EBSD, proved to be promising in the analysis of the ASR potential of sands for use in Portland cement mortars and concretes.
\end{abstract}

Keywords: ASR, EBSD, natural sand, microstructural-crystallographic quartz planes, potential reactivity.

Resumo: Este estudo envolveu a análise de várias areias naturais para verificar as possíveis causas de manifestações patológicas pela ASR. As análises foram realizadas utilizando as seguintes técnicas: difratometria de raios $\mathrm{X}$, testes acelerados de barra de argamassa (AMBT), a difração de elétrons retroespalhados e as análises químicas elementares, por FEG-SEM / EBSD / EDS. Esses experimentos permitiram identificar a presença de vários compósitos minerais (como microclina, anortita, entre outros), bem como os planos microestruturais-cristalográficos de quartzo (como o tipo Dauphiné). Dos resultados se pode inferir que as múltiplas técnicas utilizadas, especialmente a FEG-SEM/EBSD, mostraram ser promissoras na análise da reatividade potencial de areais para uso em argamassas e concretos de cimento Portland.

Palavras-chave: RAS, EBSD, areia natural, planos microestruturais e cristalográfico do quartzo, reatividade potencial.

How to cite: K. F. Portella et al., "Alkali-silica reaction (ASR) - Investigation of crystallographic parameters of natural sands by backscattered electron diffraction" Rev. IBRACON Estrut. Mater., vol. 14, no. 3, e14308, 2021, https://doi.org/10.1590/S1983-41952021000300008 


\section{INTRODUCTION}

The alkali-aggregate reaction, AAR, which is mostly represented by the alkali-silica reaction, ASR, is autogenous, inhomogeneous and occurs in certain regions of a concrete structure containing Portland cement. The result from ASR is usually an expansive gel (alkaline-calcium silica gel) that can cause damage to concrete structures and occurs in the presence of progressive and map-shaped micro-cracks. The lifetime of a civil structure depends on environmental conditions, the concrete mix design, among other factors. The presence of ASR has been detected as early as 1 year after construction completion, such as reported at the Parker dam, in California, in 1939 [1], [2].

The initial conditions for ASR to develop are associated with the presence of reactive aggregates, such as varieties of crystalline or amorphous silica and alkalis, mainly released from the cement paste. Other factors include environmental conditions, such as temperature, pressure and high moisture contents. According to the literature, the reaction mechanism involves two processes, that lead to the decomposition of the mineral structure by the formation of a sodium or potassium silica-alkaline gel [3].

The damage caused by ASR is the result of a series of sequential reactions involving the silica and alkalis present in the alkaline concrete. The damage occurs by hydration or dissolution of the solid silica contained in the reactive aggregate, generating a nano-colloidal silica (silica sol) and the transformation of silica sol to gel. Afterwards, the presence of water causes the silica gel to expand. However, as reported by Rajabipour et al. [4], the expansion mechanism depends on humidity and on how easy the transport of the solution is throughout the concrete (continuous pores, microcracks and voids).

During the reaction of the compounds, in the presence of silica and alkaline hydroxides for the formation of the gel, a difference in chemical potential arises between the gel and the substances contained in the pores of the concrete, inducing greater water adsorption and allowing its expansion [1], [5].

The kinetics of ASR also depends on the type of silica available, such as the shape in which the silica crystallized as well as the density and the surface area of the grains, since the mechanism is a result of alkali attack on the substrate. Thus, crystalline quartz aggregates with a low density of structural defects are less susceptible to the reaction with ASR, contrasting with a cryptocrystalline structure or one with a high degree of crystalline defects (deformation). Figueira et al. [1], inferred that four conditions for the occurrence of ASR have to be satisfied, which are: i) reactive silica in a critical concentration range (the source may be igneous, metamorphic and sedimentary rocks), depending on its geological origin, its composition and microstructure (such as opal, tridymite, cristobalite, volcanic acid glass); ii) a high concentration of alkalis or $\mathrm{OH}^{-}$in the solution inside the concrete pore; iii) a source of calcium ions such as portlandite (reaction inducer) to react with $\mathrm{SiO}_{2}$ sol and form the deleterious gel and, finally; iv) an optimum moisture condition to promote gel adsorption and expansion. As for the grain size, the authors inferred that the coarser particles of reactive silica (from $630 \mu \mathrm{m}$ to $1,250 \mu \mathrm{m}$ ) were the ones that resulted in greater expansions, in contrast to the smaller ones (with particle size distribution between 50 and $160 \mu \mathrm{m}$ ). With respect to the reaction rate, it was concluded that sodium hydroxides were more reactive than potassium hydroxides, for the same environment. Furthermore, an increase in the ratios of $\mathrm{Na} / \mathrm{Si}$ and $\mathrm{K} / \mathrm{Si}$ in the gel corresponds to an increase in both expansion and water absorption coefficient. Therefore, the accelerated tests are performed with immersion in a $\mathrm{NaOH}$ aqueous solution. However, for the $\mathrm{Ca} / \mathrm{Si}$ ratio, this is not a direct relationship between the increase of that ratio and the water expansions and absorptions. In this case, there was no direct relation, so for a ratio between 0.05 and 0.18 the water absorption coefficient was observed to be lower than for a range between 0.18 to 0.40 , in which the largest water expansions and absorptions coefficients were found [1], [5], [6].

According to Broekmans [7], in deformed quartz crystals, containing low-angle grain boundaries or subgrains, internal stresses or defects can be generated and accommodate foreign ions in their lattices (usually alkalis, $\mathrm{Na}^{+}$and $\mathrm{K}^{+}$), causing the rupture of local silica bonds. As a result, there is an increase in its solubility to alkalis in solution, when compared to a non-deformed quartz structure. An example of this occurrence was found in AMBT results with Norwegian mylonites, where the author identified a higher potential reactivity in these deformed rocks. However, the relationship between potential reactivity and the deformational features, such as the formation of subgrains, distortions in the crystalline lattice and Dauphiné twinning, are not always observed. This is particularly the case as structures need specific techniques rather than OM to be determined, such as scanning electron microscopy (SEM) with backscattered electron diffraction (EBSD) and elementary chemical analysis by dispersion of X-rays (EDS).

According to Tiecher et al. [8], although the angle of undulatory extinction in quartz is an essentially subjective parameter, which is difficult to measure in common thin sections of petrographic microscopes, this may be an indication of its potential reactivity in minerals. This parameter was used for the qualification of the reactive potential of some Brazilian rocks [9], [10].

Hasdemir et al. [9], studied the potential reactivity of natural sands, applying the AMBT (ASTM C 1260 [11]), petrographic analysis, scanning electron microscopy and EDS, among other techniques, concluding that the presence of reactive silica and mineral silicates from metamorphic and volcanic rock particles makes the samples potentially reactive to ASR. The authors observed that the potential damage to natural sands came from the release of silica from quartz and its polymorphs, in addition to different amounts of aluminum, calcium, potassium, sodium and magnesium from feldspars, biotite, illite and volcanic rocks. They observed that the potential reactivity of the samples was caused by their microstructural, mineralogical and chemical characteristics, with high proportions of silica (95 to $98 \%)$ and 
others chemical constituents of equal potential reactivity, resulting from quartz polymorphs with lower proportions of mineral silicates. Most of the analyzed sands were identified by means of X-ray diffractometry and mineralogical composition (quartz, feldspar, calcite, muscovite, ilite, chert/chalcedony, dolomite, epidote, and kaolinite).

In order to assess the possible causes for pathological manifestations by ASR, this study involved the analysis of some natural sand samples, by X-ray diffractometry, the accelerated test of potential reactivity, electron backscattering diffraction and elementary chemistry analyses, by FEG-SEM/EBSD/EDS. The experiments aimed the identification of the presence of several mineral composites, the evaluation of the microstructural-crystallographic planes and the establishment of their relationship with the ASR, intending a better comprehension of the mechanisms that can took place in concrete and mortars structures.

\section{MATERIALS AND EXPERIMENTAL PROGRAM}

Physicochemical and geotechnical characterization of the sands. A set of 11 samples of natural sand products of weathering of sedimentary rocks from Paraná Basin, Brazil, were collected along riverbanks and caves, according to normative procedures and general macroscopic characterizations.

Sand expansion tests. Three mortar bars of dimensions $(25 \times 25 \times 285) \mathrm{mm}$ were prepared and analyzed for each sample, with proportions of cement to aggregate of $1: 2.25$ and a water/cement of 0.47 (by mass) by the accelerated method and other standard tests [11]-[20]. After being molded, the bars were cured for $24 \mathrm{~h}$ in a humid chamber and were maintained immersed in water for $24 \mathrm{~h}$ at $80{ }^{\circ} \mathrm{C}$. After curing, they were subjected to a solution of sodium hydroxide $(\mathrm{NaOH})$ at $1 \mathrm{~N}$, at a temperature of $80^{\circ} \mathrm{C}$, with expansion being measured daily for 30 days.

To determine the potential reactivity of the sands in relation to expansion by ASR, 5 samples were selected from the characterized lots ranging from the largest to the smallest expansion values. To characterize the mineralogy, X-ray diffraction and field emission scanning electron microscopy (FEG-SEM), equipped with an energy dispersive X-ray spectrometer (EDS) and a detector of electron backscatter diffraction (EBSD), were applied. Among the samples considered, the two largest and smallest expansion by ASR results were also analyzed by optical polarized microscopy, $\mathrm{OM}$, to compare both techniques.

The X-ray diffractometer, by polycrystalline powder's method, was done at Brucker equipment, model D8 Advance, with a $\mathrm{Cu}$ X-ray tube, $1=1.54060 \AA$, operating at a current of $25 \mathrm{~mA}$ and a voltage of $40 \mathrm{kV} ; 0.02 \mathrm{~s}$ step, $0.1 \mathrm{~s}$ time per step; with $\Theta / 2 \Theta$ scanning between 5 and $70^{\circ}$. The samples were analyzed after passing through a $0.075 \mathrm{~mm}$ mesh sieve.

Microstructures, mineralogy, and chemical and phase compositions of the samples. Initially all the samples were observed in a Leitz polarized light microscope model Ortholux 2 Pol-BK. The light microscope allows a comprehensive analysis of microstructures and mineralogy of the sample. However, most of the observations done in the optical microscope (OM) were qualitative and fine-sized minerals were almost impossible to identify. To overcome the limitations of the OM, X-ray diffraction and FEG-SEM/EBSD were applied, by Kernel average misorientation (KAM) and Grain Reference Orientation Deviation (GROD) maps methods.

The FEG-SEM used for this analysis was a TESCAN, model MIRA 3 LM, with an EDS and EBSD from Oxford Instruments. A set of applications integrated to the Oxford Aztec 3.3/Channel 5 platform was used for the acquisition and processing of EDS and EBSD data. In addition, the following analysis parameters were used: acceleration voltage of $15 \mathrm{kV}$; beam current intensity of $18 \mathrm{~nm}$, working distance between 15 and $21 \mathrm{~mm}$ and scanning depth mode.

The aggregates were mounted in epoxy resin. The mounted samples were ground with 240, 600 and 1000 grit sandpaper to remove the excess of resin. The samples were then polished in an automated polishing machine Buehler Metaserv 250, with diamond crystalline suspension with particle sizes of 9, 6, 3, 1, $0.25 \mu \mathrm{m}$ for 30 minutes in each size. The final polishing was carried out in an alumina solution of $0.05 \mu \mathrm{m}$ for $60 \mathrm{~min}$ followed by chemical mechanical polishing in an aqueous solution of colloidal silica, $20 \mathrm{~nm}$, for $60 \mathrm{~min}$ in Buehler Minimet Polisher. The surface quality images, or zero solutions of each one was kept close to $15 \%$. All samples were grounded with conductive paint and taped to prevent the samples from charging.

The application of the FEG-SEM/EBSD. The Channel 5 bundled software was used for FEG-SEM/EBSD analyses. The representation of the data was done by generating maps that included phase distribution, grain boundaries and average misorientations. The later provide a picture of the deformation of the samples by distributions of the local geometric necessary dislocations (GND) as the average misorientation angles and axes in different parts of the grain. The modal distribution of minerals in percentage of area occupied by a specific phase was quantified as well as the size distribution from the EBSD analyses. The misorientation angles, defined by the rotation necessary to bring together two crystal lattices, were the base for representing the maps of intracrystalline deformation of sand grains.

The approaches of using FEG-SEM/EBSD in an ASR investigation. The plasticity of crystalline materials usually results in a local rotation in the crystal, for which the EBSD is the appropriate instrument for measuring. Typical resolution values for the disorientations that can be measured in the EBSD are in the order of $0.5^{\circ}$ [21], [22]. EBSD grain edges or contours are determined as locations where the difference between orientations of adjacent pixels is of 
some critical value. In this work, low-angle grain edges were plotted with misorientation angles between $1^{\circ}$ and $10^{\circ}$. Misorientation higher than $10^{\circ}$ was marked on the map as high angle grain boundaries. There are special boundaries for quartz grains where two neighboring lattices are disorientated by $60^{\circ}$. This is a typical relationship between quartz crystals defined as Dauphiné Twinning where the angle around which the twinned crystals are rotated is parallel to the [0001] crystal axis. It can be caused by quartz symmetry transformation as well as by deformation. Another approach in the evaluation of intracrystalline deformation was made from the analysis of local misorientation. Local misorientation was characterized by a change in orientation caused by geometrically necessary dislocations (GND).

The local misorientation or kernel average misorientation (group of pixels), KAM, was plotted onto a map, which revealed areas of contrast in dislocation densities in a scale of colors. The average values of these misorientations, after scanning a certain area of the grain, reflected the history of its deformation. Through this technique it is also possible to quantify and map the average misorientation around a measured point in relation to a group of previously established neighboring points, that is, a group of pixels or kernels, these being larger in deformed grains due to the higher density of dislocations.

An additional way of evaluating the internal deformation of the grain and substructures (subgrains), is the analysis of the grain reference orientation deviation (GROD) angle. This is a map component where the average orientation is determined for each grain based on the user-defined grain detection. The deviation angle from this mean orientation is plotted for each pixel belonging to a grain. The GROD parameter is often used in quantifying the recrystallization process to separate deformed and recrystallized grain populations. This is due to recrystallized strain-free grains having lower GROD value.

\section{RESULTS AND DISCUSSIONS}

General characteristics of natural sands. In Table 1, the mesoscopic characteristics of natural sands are presented. Grains showed a wide range of sizes and are basically composed by quartz grains, fragments of sandstones and lesser proportions of granitic rocks (quartz and feldspars).

Table 1. Geotechnical characteristics of the sands collected and analyzed for ASR potential reactivity [23]-[27].

\begin{tabular}{|c|c|c|}
\hline Samples & Origins and geological units & $\begin{array}{l}\text { Technical features } \\
\end{array}$ \\
\hline 624.18 & $\begin{array}{l}\text { River: alluvial deposits; migmatite } \\
\text { gneissic complex }\end{array}$ & $\begin{array}{l}\text { Sub-angular grains; rounded grains with an opaque and irregular } \\
\text { surface; and heterogeneous particle size distribution. }\end{array}$ \\
\hline 030.18 & $\begin{array}{l}\text { Cave: alluvial deposits; Campo Mourão } \\
\text { formation, Itararé group }\end{array}$ & $\begin{array}{l}\text { Angular to sub-angular grains; sharp edges; irregular surface; concave } \\
\text { and convex faces; heterogeneous particle size distribution }\end{array}$ \\
\hline 025.18 & $\begin{array}{l}\text { Cave: alluvial deposits: Campo Mourão } \\
\text { formation, Itararé group }\end{array}$ & $\begin{array}{l}\text { Angular to sub-angular grains; sharp edges; irregular surface; concave } \\
\text { and convex faces; heterogeneous particle size distribution }\end{array}$ \\
\hline 100.18 & River: Ponta Grossa formation & $\begin{array}{l}\text { Rounded grains; opaque surface; some angular grains; heterogeneous } \\
\text { granulometric composition, with millimeter to submillimeter grains. }\end{array}$ \\
\hline 024.18 & $\begin{array}{l}\text { Cave: alluvial deposits: Campo Mourão } \\
\text { formation, Itararé group }\end{array}$ & $\begin{array}{l}\text { Angular to sub-angular grains; sharp edges; irregular surface; concave } \\
\text { and convex faces; grains of mafic minerals are present. }\end{array}$ \\
\hline 029.18 & $\begin{array}{l}\text { River: alluvial deposits; Campo Mourão } \\
\text { formation, Itararé group }\end{array}$ & $\begin{array}{l}\text { Angular to sub-angular grains; sharp edges; irregular surface; concave } \\
\text { and convex faces; heterogeneous particle size distribution }\end{array}$ \\
\hline 718.18 & River: alluvial deposits; Caiuá formation & $\begin{array}{l}\text { Rounded grains; polished and shiny surfaces which suggest transport } \\
\text { in water; homogeneous granulometric distribution. }\end{array}$ \\
\hline 716.18 & River: alluvial deposits; Caiuá formation & Rounded grains; polished and brilliant surfaces \\
\hline 032.18 & River: Ponta Grossa formation & $\begin{array}{l}\text { Sub-angular grains; polished surface, vitreous shine and subordinate } \\
\text { round grains with an opaque aspect; homogeneous granulometric } \\
\text { distribution. }\end{array}$ \\
\hline 101.18 & Cave: Ponta Grossa formation & $\begin{array}{l}\text { Rounded to sub-rounded grains; angular edges; some with an opaque } \\
\text { surface; millimeter to submillimeter; heterogeneous granulometry. }\end{array}$ \\
\hline 031.18 & River: Ponta Grossa formation & Rounded grains predominant to sub-rounded; matte appearance. \\
\hline
\end{tabular}

The samples came from caves and rivers in alluvial deposits and rock formations, such as: (i) the Caiuá type is represented mainly by purple sandstones, in an area corresponding to approximately $30,000 \mathrm{~km}^{2}$ [23]; ii) the Ponta Grossa formation is composed by dark fossiliferous shales and clay of marine origin [24]; iii) in Campo Mourão, samples came from Itararé Group is represented by shale, diamictite, sandstone and, conglomerate [25]; and iv) a fourth type of samples were collected in the migmatite gneiss complex, represented by banded, mylonitized gneisses [26]. More details of these geologic area are reported by Miranda et al. [27].

Optical microscopy images of natural sands examples from migmatite gneissic complex, Campo Mourão, Ponta Grossa and Cauá formations, were shown in Figure 1. 


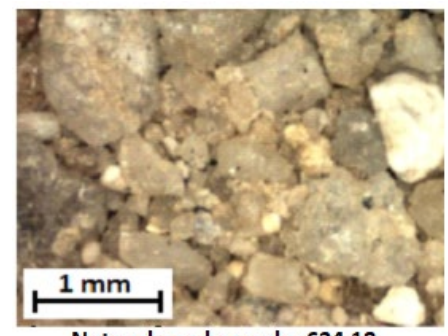

Natural sand sample: 624.18

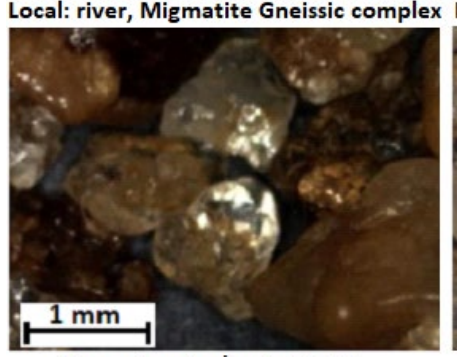

Natural sand sample: 716.18

Local: river, Caua formation

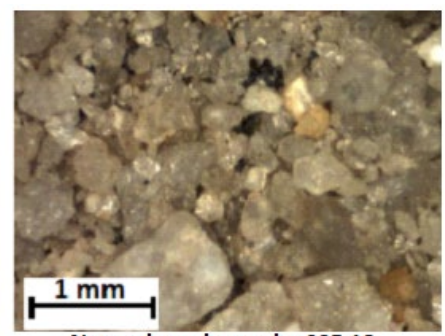

Natural sand sample: 025.18

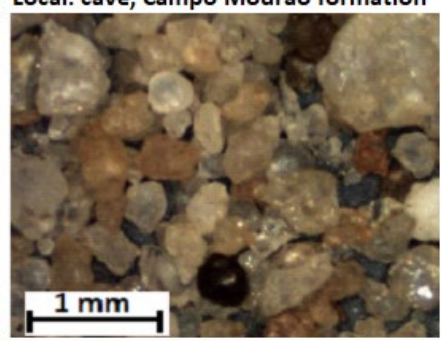

Natural sand sample: 031.18 Local: river, Ponta Grossa formation

Figure 1. Images, by optical microscopy, of some natural sands from the rock formations highlighted in Table 1.

Physicochemical characterizations of sands. The physical and chemical properties measured are shown in Table 2 . The fineness modulus and the powdery material content were $(2.84 \pm 0.01)$ and $(3.10 \pm 0.02) \%$, respectively, for sample 624.18 , and for sample 031.18 of $(1.82 \pm 0.01)$ to $(0.20 \pm 0.01) \%$, respectively. The samples had the highest and lowest percentage of expansion, respectively.

Potential reactivity and mineral phases by XRD. Table 2 shows the results of the ASR potential of 11 sand samples which $73 \%$ of them presented ASR potential, with average expansions above the standard limit of $0.19 \%$, in 30 days [12].

The following samples were chosen in a decrescent order of expansion: 624.18 , with $0.36 \%$ expansion; 025.18 , with $0.30 \% ; 716.18$, with $0.21 \% ; 032.18$ with $0.15 \%$; and 031.18 , with $0.09 \%$. They represent natural sands according to the microstructural and crystallographic characteristics of the quartz grains as well as with respect to the proportions of powdery fraction of the samples.

Table 2. Results of the physicochemical and expansion tests of the 11 sand samples evaluated applying the standards [11]-[20].

\section{Sand samples}

\begin{tabular}{|c|c|c|c|c|c|c|c|c|c|c|c|}
\hline Properties & 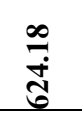 & $\frac{\infty}{\dot{\rho}}$ & $\stackrel{\infty}{\stackrel{\infty}{8}}$ & $\stackrel{\infty}{\stackrel{\infty}{d}}$ & 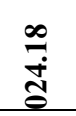 & 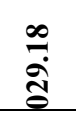 & $\stackrel{\infty}{\stackrel{\infty}{\pi}}$ & $\frac{\infty}{6}$ & $\begin{array}{l}\infty \\
\stackrel{\infty}{\mathbf{\theta}}\end{array}$ & $\stackrel{\infty}{\stackrel{\infty}{\Xi}}$ & $\stackrel{\infty}{\stackrel{\infty}{8}}$ \\
\hline Fineness modulus & 2.84 & 3.29 & 2.39 & 3.32 & 2.38 & 3.11 & 2.00 & 2.89 & 2.60 & 1.90 & 1.82 \\
\hline Clay content, \% & 0.20 & 0.50 & 1.80 & 0.40 & 0.20 & 0.40 & - & 0 & 0 & 0.10 & - \\
\hline Powdery material, \% & 3.10 & 0.40 & 1.40 & 1.90 & 3.00 & 0.20 & 0.10 & 0 & 0.40 & 1.90 & 0.20 \\
\hline Expansion, \% & 0.36 & 0.31 & 0.30 & 0.30 & 0.29 & 0.28 & 0.24 & 0.21 & 0.15 & 0.12 & 0.09 \\
\hline
\end{tabular}

Figure 2 shows the expansion curves for samples $624.18,024.18$ and 716.18, which presented values above the standard limit of expansion by NBR 15577 [12], but similar method of preparation of ASTM C1260 [11]. Samples 032.18 and 031.18 presented lowest expansion percentage. 

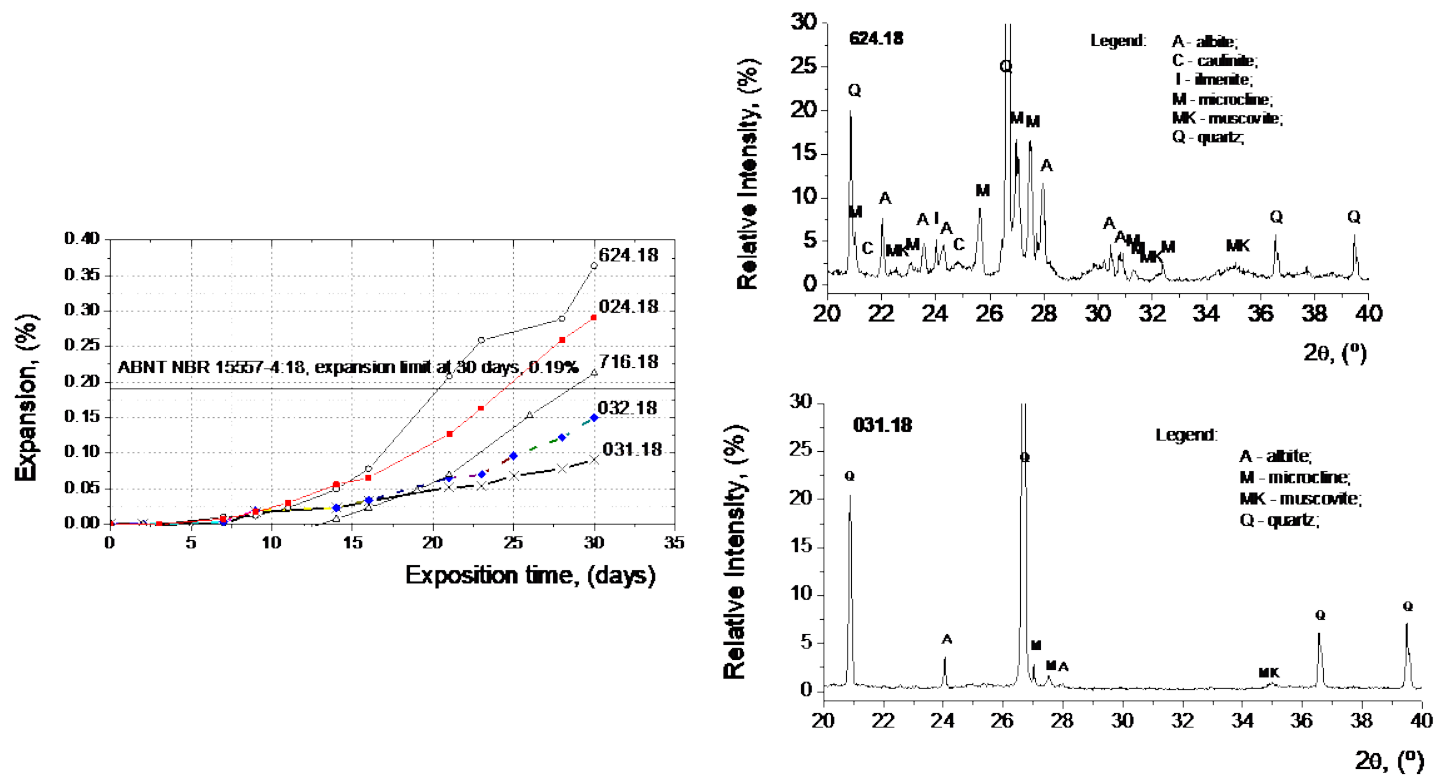

Figure 2. ASR potential reactivity for sand samples on the left. On the right, the XDR results for samples with the highest (624.18) and lowest (031.18) expansion rates.

When analyzing the mineral composition of samples 624.18 and 031.18 by XRD ( 20 to $40^{\circ}$, in $2 \Theta$, and from 0 to $30 \%$ in relative intensity), with the highest and lowest expansion results, at least two variables were considered. The first and more straightforward one was the high amount of reactive minerals, such as feldspars, found in samples with high expansion rates, as seen in Table 3. Secondly, the microstructures and crystallographic aspect of the samples were considered, as discussed by Bauer et al. [28], where the silica with a very low state of crystallization is very reactive in an alkaline solution. The sample 624.18 , for example, had the highest potential reactivity $(0.36 \%)$, and contains the lowest quartz content $(44.90 \%)$ compared to the other samples. On the other hand, the sample 031.18 had the highest amount of quartz $(62.27 \%)$ and the lowest expansion rate of just $0.09 \%$. In addition, the proportion of feldspar minerals in sample 624.18 was considerably high and may also play an important role in increasing the potential reactivity of ASR in this sample. However, the analysis of sample 716.18 showed that its quartz content was like that of sample 031.18. Therefore, the mineral composition as well as grain size (fineness), which were similar in both samples, could not be the only factors that contributed to the potential reactivity of ASR. Thus, microstructures and crystallographic aspects of the grains and aggregates were considered. The importance of this study corroborates the research carried out by Monteiro et al. [29], that concluded from the studies with mortars prepared with granodiorite, mylonite, phyllonite, and ultramylonite from the Santa Rosa mylonite zone in southern California, that the resulting ASR expansions were dependent on the degree of deformation of the analyzed rocks and their granulometric distributions.

Table 3. Semiquantitative proportions of mineralogical phases, by FEG-SEM/EBSD, in natural sands.

\begin{tabular}{|c|c|c|c|c|c|c|}
\hline \multirow{2}{*}{ Sand sample } & \multicolumn{6}{|c|}{ Type and content of mineral phases in natural sands, $\%$} \\
\hline & Quartz & Anorthite & Albite & Microcline & Biotite & Muscovite \\
\hline 624.18 & 44.90 & 12.01 & 8.33 & 22.82 & 6.02 & 5.92 \\
\hline 030.18 & 66.73 & 7.58 & 6.21 & 9.06 & 5.47 & 4.96 \\
\hline 100.18 & 72.11 & 6.59 & 4.96 & 7.81 & 4.04 & 4.50 \\
\hline 025.18 & 65.74 & 7.46 & 6.49 & 11.00 & 4.48 & 4.83 \\
\hline 024.18 & 48.46 & 11.27 & 9.80 & 16.10 & 7.10 & 7.27 \\
\hline 029.18 & 60.00 & 8.64 & 8.04 & 11.12 & 6.87 & 5.33 \\
\hline 718.18 & 61.03 & 9.24 & 7.67 & 11.04 & 4.95 & 6.07 \\
\hline 716.18 & 63.00 & 8.35 & 7.36 & 10.32 & 5.11 & 5.85 \\
\hline 032.18 & 62.14 & 9.42 & 6.73 & 10.06 & 5.50 & 6.15 \\
\hline 101.18 & 65.95 & 8.01 & 6.62 & 8.28 & 5.44 & 5.71 \\
\hline 031.18 & 62.27 & 8.34 & 7.31 & 8.74 & 7.51 & 5.83 \\
\hline
\end{tabular}


Semi-quantitative investigation of mineral phases. In Figure 3, the mineral composition was represented as a phase map obtained by simultaneous analyses of EDS (elemental chemical composition) and EBSD (crystallographic symmetry). The mineralogy was shown in colors and modal proportions could be calculated by the area occupied by each phase on the map. Quartz was the main mineral found in all samples with proportions varying from 44.9 to $65.77 \%$. $\mathrm{K}, \mathrm{Na}$ and $\mathrm{Ca}$ feldspars were the second major constituents with a wide range of proportions. Grain size distributions were polymodal and had similar distribution throughout the samples and could be an important metric when the reactivity of the sample was being analyzed. But just considering one example, looking at the most and least reactive samples in the whole spectrum, 624.18 and 031.18 , both were samples with smaller grain sizes. Therefore, the grain size alone could not be accountable for the reactivity of the samples.
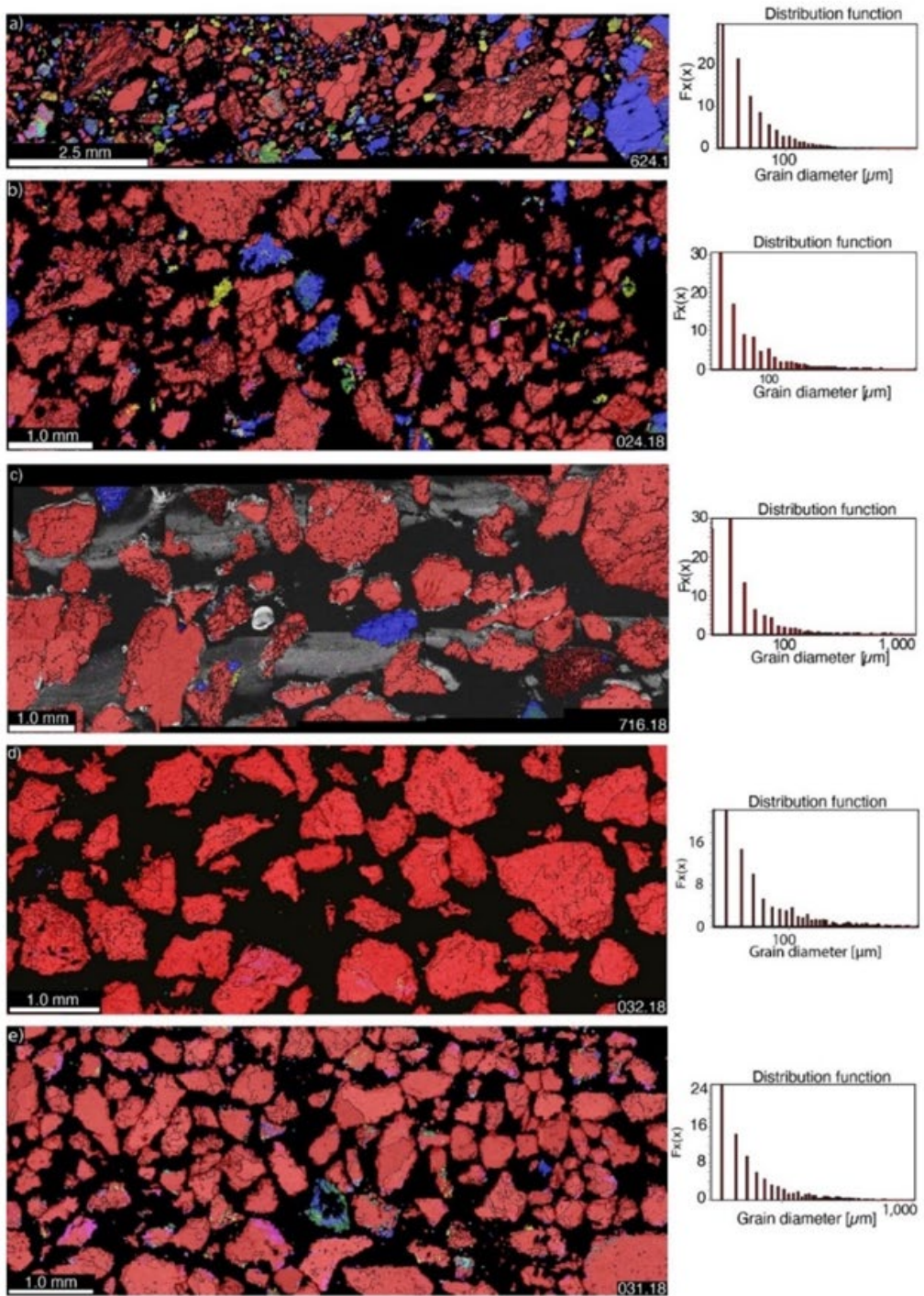

quartz $\square$ anorthite $\square$ albite $\square$ microcline

biotite $\square$ muscovite

Figure 3. FEG-SEM/EBSD micrographic images representing the mineral phase maps of the natural sand samples, tested for ASR expansion, and the histograms of each distribution function.

Figure 4 shows maps of local misorientation (KAM) for the analyzed samples. These maps had a gradation in colors starting from blue, where grains had the lowest misorientation angles to green, yellow, and red where misorientations 
reach a user-defined limit $\left(<10^{\circ}\right)$. The sample with the largest expansion rate (624.18) had the widest variation in misorientation angle for quartz grains and consequently was the most deformed. Conversely, samples 032.18 and 031.18 were those with the lowest density of the GND, which translates to less variation in color and therefore less variation in misorientation angles.
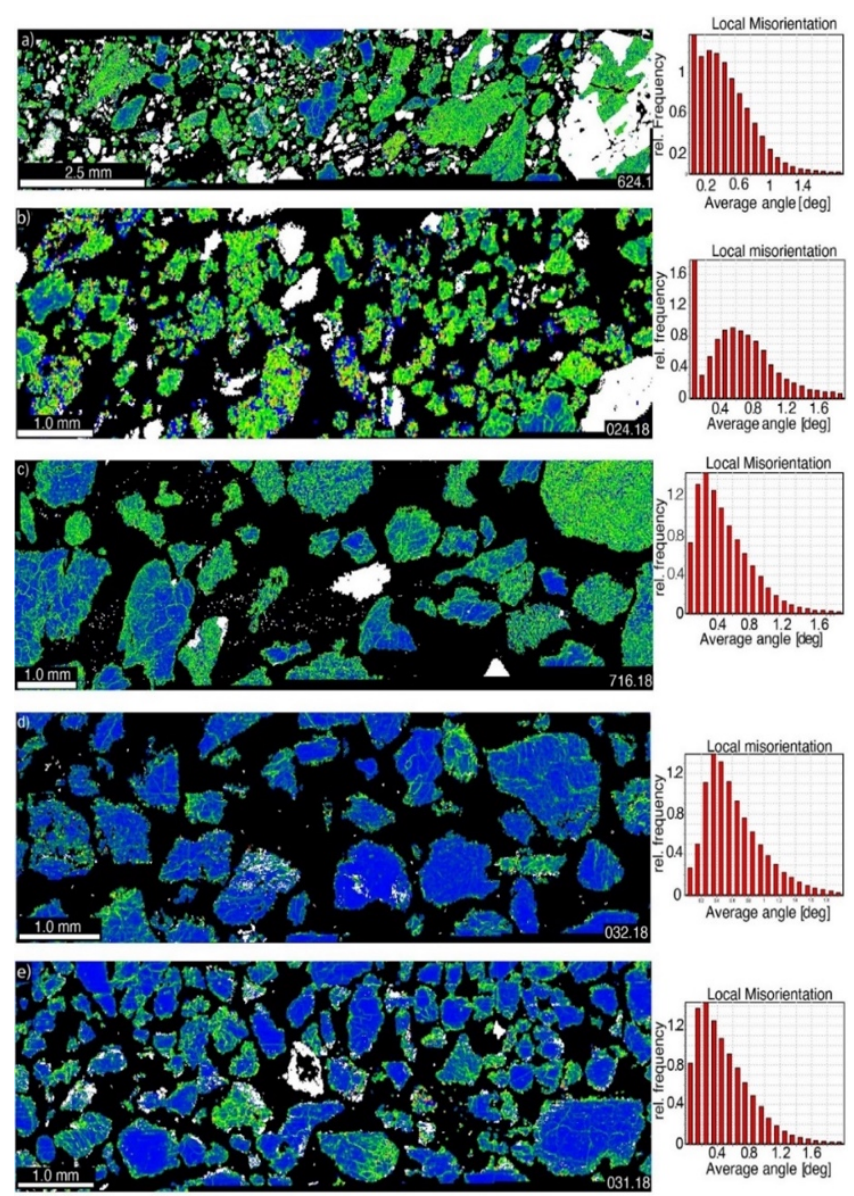

Figure 4. Local misorientation map (Kernel average misorientation, KAM) of quartz grains, based on local distortion of crystal lattice caused by geometrically necessary dislocations (GND) and the local misorientation histograms of each sand sample. Note: grains colored in blue have low dislocation densities contrasting with those in green, yellow, orange, and red, which have an increasing density of dislocations. Areas in white correspond to grains other than quartz.

A grain reference orientation deviation (GROD) angle map component is depicted in Figure 4. GROD angle maps help to visualize substructures inside the grain. The average misorientation is determined for each grain based on the user-defined grain detection. The deviation angle from this mean orientation was plotted for each pixel. This map is useful to highlight deformation in grains, even showing the smallest misorientation angle pixel by pixel in a deformed single crystal. On the maps of Figure 5 for grain detection, a critical misorientation value of $10^{\circ}$ was set for the KAM maps.

Maps of grain boundaries were also plotted to help visualizing if the sands were composed by single or polycrystals. Most sands were presented single crystals where low angle boundaries (in red lines) predominate. All grains were white colored to highlight the grain boundaries. High angle boundaries are in black lines. The most deformed samples have high densities of subgrain boundaries, caused by the arrangement of necessary geometric dislocations. This can also be visualized under the polarized microscopes as undulatory extinction. The reactivity of the sand grains in relation to ASR is linked to the density of subgrain boundaries. Sample with the highest densities of subgrain boundaries (624.18) was the most reactive and samples with lowest densities (032.18 and 031.18) showed the lowest expansion rate, being the less reactive among the analyzed samples. 

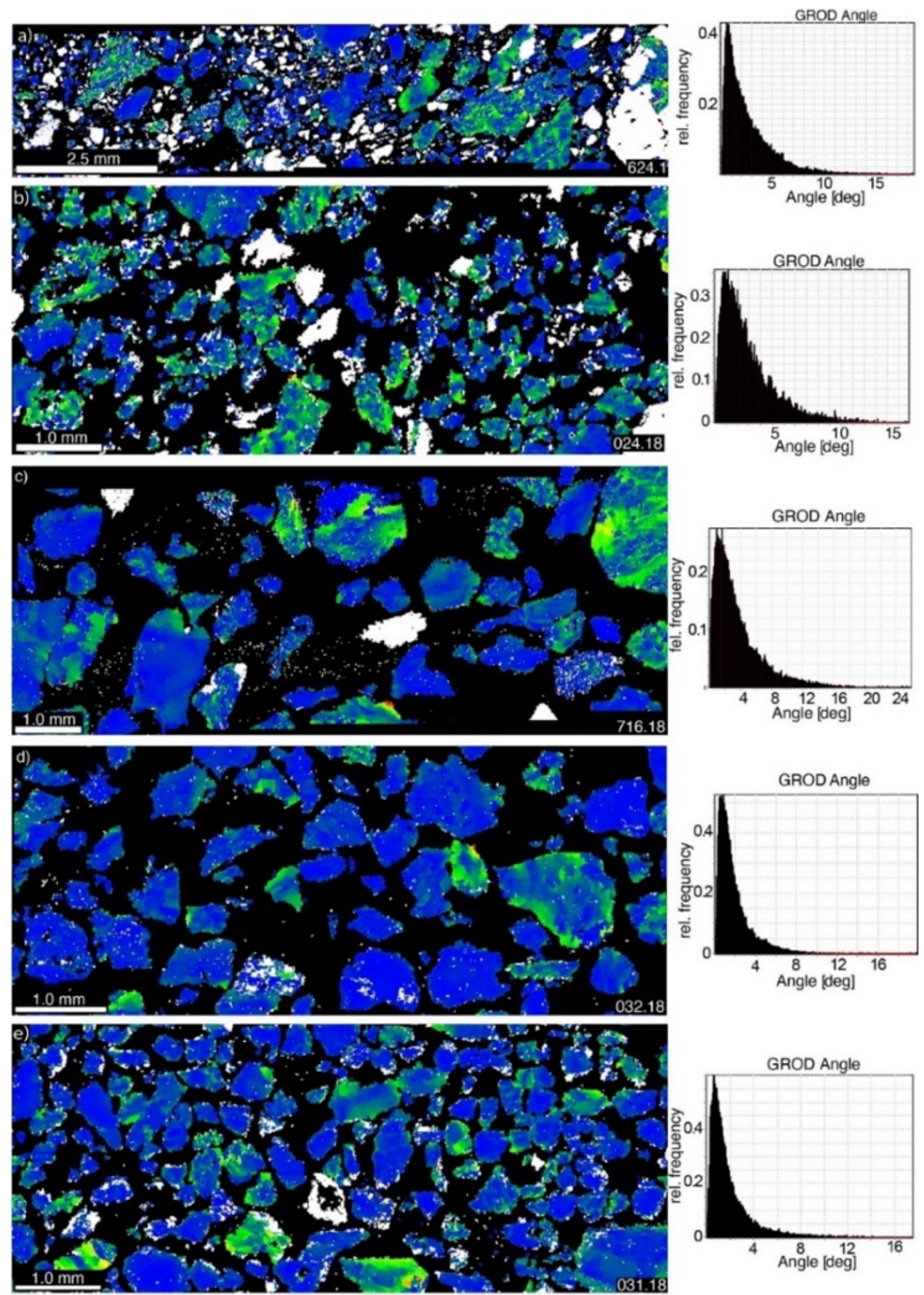

Figure 5. GROD angle map highlighting areas of deformation and the GROD angle histograms for each sample. Note: the less deformed grains are shown in blue and the most deformed ones in yellow to green. Minerals other than quartz are in white. 
There was not a significant variation in the distribution of high boundaries between the samples that can be related to the rate of expansion observed. In general, sands are composed predominantly by polycrystalline quartz grains as seen in Figure 6. To test if the twin boundaries could play a role on the reactivity of the sand grains, Dauphine twin boundaries for quartz grains were also plotted. There was no effective relationship between the density of twin boundaries in the samples and their degree of reactivity. In fact, the two less reactive samples, 032.18 and 031.18 , with lowest expansion rates, were the ones with the highest frequency of twin boundaries in the quartz sands.

In the Dauphiné Twinning a characteristic peak of misorientation angle around $60^{\circ}$ (in red colors) appears in the histogram of misorientation angle distribution showed in the same figure. The higher angles of the grain boundaries are presented in green colors. In the twinning relationship, the neighboring crystal lattices were separated by a rotation around the crystallographic axis $\mathrm{c}$, leading to a superposition of the positives $<\mathrm{a}>$ axes of one crystal over the negatives $<a>$ axes of the other crystal that makes up the twinned pair. For that reason, the twined pars of quartz crystals are indistinguishable under the optical microscope and can only be determined by diffraction methods (EBSD) [8]. These types of twinning can be generated either by growth or by deformation and, in the most cases, are not associated with the reactivity of sand crystals. However, as previously mentioned by Broekmans, 2004, working with Norwegian mylonites, there might be internal stresses or defects in the crystal that facilitate the accommodation of foreign ions into the silica network (as $\mathrm{Na}^{+}$and $\mathrm{K}^{+}$), causing the rupture of its bonds, mainly in the regions of the crystals under high stress (deformed). Sites of high deformation in the crystal lattice, such as subgrains, might enhance the solubility of aqueous solutions rich in alkalis. This is due to the higher diffusivity ratio along the dislocation lines in highly deformed crystals when compared with undeformed quartz lattice with fewer dislocations.

The most reactive samples, 624.18 and 024.18 showed in Figure 3 share some characteristics that together make them prone to react in alkaline solutions. The most remarkable is the dislocation density, discussed earlier, the large proportions of reactive minerals, like feldspar, and the relatively fine size of sand grains for both samples, as shown in Tables 2 and 3 (powdery material: $3.1 \%$ and 3.0\%; and fineness moduli: 2.84 and 2.38, respectively).

However, if only the content of potential reactive minerals were considered, the proportions of these minerals themselves could not be accountable for the differences in expansion rates as observed in the samples with expansion rates above the ABNT NBR limit of $0.19 \%$, i.e., samples $716.18(0.24 \%), 024.18(0.29 \%)$ and $624.18(0.36 \%)$. In these samples the bulk feldspar contents (the most reactive mineral in the system) are considerably different. Nevertheless, if samples 024.18 and 716.18 were compared to the less reactive 031.18 , the difference in the felspar content was not that much to justify the differences in reactivity between them. Therefore, other factors must be considered to explain how these samples have a contrasting behavior in terms of ASR reactivity. The only remarkable difference relies on the degree of deformation unveiled by the misorientation maps, where the most reactive samples correspond to those with widest variation in misorientation angles, while the samples with the shorter range of misorientation angles were the least reactive. The most deformed samples had larger numbers of subgrains. Subgrain walls, where necessary geometric dislocations are arranged, are sites of mismatch between adjacent sublattices. Therefore, this might act as a faster path for ion diffusivity, which could speed up the rate of reactions when compared to crystals with a lower density of GND. Crystal lattices with plenty of defects are prone to react when in contact with alkaline solutions.

Samples 716.18 and 032.18 with, respectively, $0.21 \%$ and $0.15 \%$ of expansions, above and below of the standardized limit of $0.19 \%$ (NBR 15577: 2008), possibly had a great contribution of intracrystalline defects in quartz, since their fineness moduli and powdery materials, as well as their proportions of potentially reactive minerals (aluminum silicates), were similar (Tables 2 and 3 for comparison as well as phase maps of Figure 3). Additionally, it was verified that in the studied samples there was no evidence of formation of new grains (dynamic recrystallization). Mostly subgrains were observed in the misorientation maps, in which the monocrystalline particles show substructures with angular deviation up to $10^{\circ}$, as well as Dauphiné twin boundaries with misorientation angles around $60^{\circ}$.

The FEG-SEM/EBSD/EDS techniques were decisive for the analyses of the samples, since they allowed a comprehensive investigation of all parameters involved in the reaction of minerals with alkaline aqueous solutions. All the parameters: i) identification and quantification of mineral composition in the mixture; ii) microstructural characteristics of the constituent particles of the aggregates; and iii) the semi-quantitative determination of the degree of deformation of the quartz grains, either acting combined or individually, were the ultimate cause of expansion found in this assessed. 

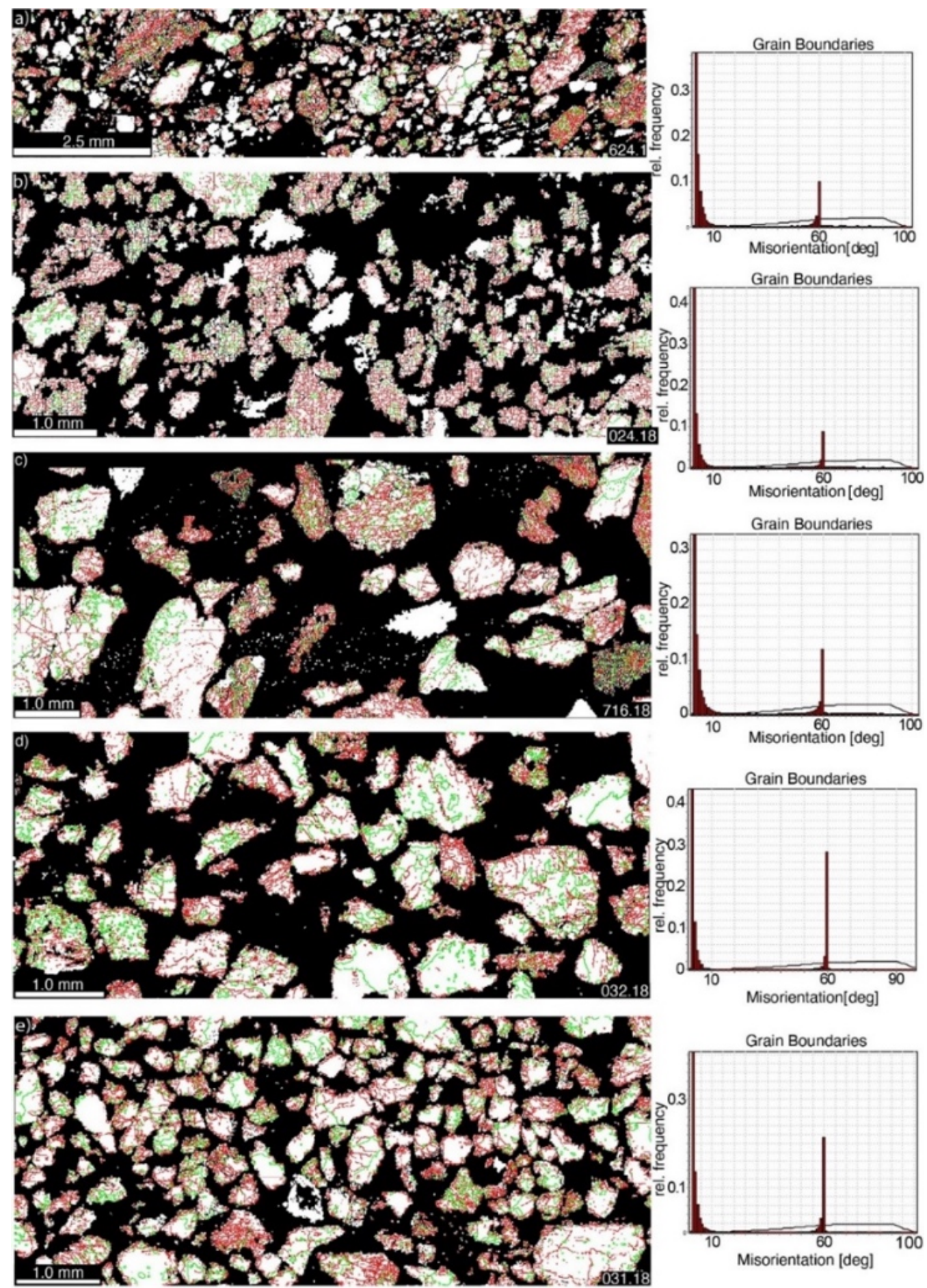

Figure 6. Images of the grain boundary maps of the sand samples and the histogram of misorientation angle distribution. Note: the color in red present the misorientation angle around $60^{\circ}$ (Dauphiné Twinnin), and the green color, the higher angles of the grain boundaries or dislocations).

As investigated by Hasdemir et al. [9], and reported earlier, it was found in this research that the expansions by ASR were also a consequence of both the presence of silicate minerals and the deformed quartz grains in the natural sands. From the KAM images in Figure 4, it could be inferred that in samples with expansions greater than 0.19\%, after 30 days, the degree of semi-quantitative deformation measured in the quartz was equal to $51.02 \%$ for sample 624.18 
( $0.36 \%$ expansion); $60.70 \%$, for sample 030.18 ; and $67.90 \%$, for sample 025.18 , with about the same expansion of $0.30 \%$ in 30 days. For samples with expansion rates below the limit of $0.19 \%$, after 30 days, the degree of deformation of quartz grains was around $30 \%$ or less, with $22.40 \%$ for sample 032.18 ( $0.15 \%$ expansion); $30.00 \%$ for sample 101.18 ; and $29.10 \%$ for sample 031.18 , which had an average expansion of around $0.20 \%$ after 30 days.

In the case of sample 624.18, it was not easy to infer which factor contributed to the resulting expansion, since this sample has the highest proportion of aluminosilicates and fine particle sizes. Nevertheless, it is the sample with the largest proportion of deformed quartz grains, and with the highest distorted crystal lattices. However, other samples had lower content of feldspar minerals and similarities in density of crystal defects and, despite of that, they showed expansion rates closed to sample 624.18. Therefore, the arrangement of crystal defects as necessary geometric dislocation that cause local disorientation of the crystal seems to be the main cause of expansion measured in the natural sands analyzed.

\section{CONCLUSIONS}

The investigation of fine aggregates of natural sand by X-ray diffraction, accelerated potential reactivity test, elementary chemistry composition and, specially, backscattered electron diffraction technics, indicated that the primary causes of expansion or pathological manifestations by ASR resulted mainly by the presence of intracrystalline deformation in the quartz grains.

By the results obtained, it could be considered for the effectiveness of the use of the EBSD technique, complementing the elucidation of the potential reactivity of the aggregates used in Portland cement mortars and concretes. However, there were limitations observed and resolved by pre-treatment by polishing the samples to the mirrored surface, to reduce artifacts on the maps (reduction of the zero solution). The degree of quartz deformation assessed in the studied samples, obtained from misorientation data, was determinant to the evaluation of the potential reactivity of material used.

As additional advantages from EBSD analysis, it could be inferred by the shorter time of analysis and interpretation of a possible trend of expansion of the samples and their use for evaluating coarse aggregates, foreseeing their ASR reactivity in a less subjective way.

As a general alert to the public, $73 \%$ of the analyzed sands were considered to have potential reactivity for ASR from accelerated tests, with results above the limits recommended by Brazilian standard. Therefore, it is recommended, in addition to the current tests applied to the evaluation of reactivity of the geological materials used in civil construction, the implementation of a routine procedure for the analyses of deformation by means of EBSD.

\section{ACKNOWLEDGEMENTS}

This work had financial and infrastructure support from Furnas Centrais Elétricas S.A./ANEEL/Lactec, P\&D 03941504-2015; Lactec - Professional Master's; CNPq DT, process number 302672/2016. The authors would also like to thank Lactec; Professional Master course; UFPR PPGECC; CNPq DT, process number 302672/2016//308777/2020-4, and law 8010/90; and COPEL, R\&D 6491-0301/2013, LI 08/2468574-9 DI 09 / 0457074-0. L. Lagoeiro acknowledges the support from the National Council for Research and Development (CNPq) processes 425412/2018-0 and 305232/2018-5. Our thanks to Henrique Lagoeiro for the English review.

\section{REFERENCES}

[1] R. B. Figueira et al., "Alkali-silica reaction in concrete: mechanisms, mitigation and test methods," Constr. Build. Mater., vol. 222, pp. 903-931, 2019.

[2] R. G. Charlwood and Z. V. Solymar, "Long-term management of AAR-affected structures, an international perspective," in Proc. 2nd Int. Conf., Alkali-Aggregate Reactions in Hydroelectric Plants and Dams, Chattanooga, Tennessee, 1995, pp. $19-57$.

[3] L. S. Dent-Glasser and N. Kataoka, "The chemistry of "alkali-aggregate" reaction," Cement Concr. Res., vol. 11, no. 1, pp. 1-9, 1981.

[4] F. Rajabipour, E. Giannini, C. Dunant, J. H. Ideker, and M. D. A. Thomas, "Alkali - silica reaction: current understanding of the reaction mechanisms and the knowledge gaps," Cement Concr. Res., vol. 76, pp. 130-146, 2015.

[5] S. Multon, A. Sellier, and M. Cyr, "Chemo-mechanical modeling for prediction of alkali silica reaction (ASR) expansion," Cement Concr. Res., vol. 39, no. 6, pp. 490-500, 2009., http://dx.doi.org/10.1016/j.cemconres.2009.03.007.

[6] N. P. Hasparyk, P. J. M. Monteiro, and H. Casarek, "Effect of silica fume and rice husk ash on alkali-silica reaction," ACI Mater. J., vol. 97-M57, pp. 486-492, 2000. 
[7] M. A. T. M. Broekmans, "Structural properties of quartz and their potential role for ASR," Mater. Charact., vol. 53, no. 2, pp. 129140, 2004.

[8] F. Tiecher, M. E. B. Gomes, D. C. C. Dal Molin, N. P. Hasparyk, and P. J. M. Monteiro, "Relationship between degree of deformation in quartz and silica dissolution for the development of alkali-silica reaction in concrete," Materials, vol. 10, no. 9, pp. 1022, 2017, http://dx.doi.org/10.3390/ma10091022.

[9] S. Hasdemir, A. Tugrul, and M. Yilmaz, "Evaluation of alkali reactivity of natural sands," Constr. Build. Mater., vol. 29, pp. 378$385,2012$.

[10] N. P. Hasparyk, "Investigação dos mecanismos de reação álcali-agregado: efeito da cinza de casca de arroz e da sílica ativa,” M.S. thesis, Fac. Eng. Civ., Univ. Fed. Goiânia, Goiás, 1999.

[11] American Society for Testing and Materials, Potential Alkali Reactivity of Aggregates (Mortar-Bar Method), ASTM C1260, 2014.

[12] Associação Brasileira de Normas Técnicas, Aggregates - Alkali Reactivity of Aggregates. Parts 1-5: Petrographic Analysis for Evaluation of the Potential Reactivity of Aggregates with Alkali Compounds from Concrete, NBR 15577, 2018.

[13] Associação Brasileira de Normas Técnicas, Agregado Miúdo - Determinação da Absorção de Água, ABNT NBR NM $30,2001$.

[14] Associação Brasileira de Normas Técnicas, Agregados - Determinação do Material Fino que Passa Através da Peneira 75 um, por Lavagem, ABNT NBR NM 46, 2003.

[15] Associação Brasileira de Normas Técnicas, Agregado Miúdo - Determinação de Impurezas Orgânicas, ABNT NBR NM 49, 2001.

[16] Associação Brasileira de Normas Técnicas, Agregado Miúdo - Determinação da Massa Especifica e Massa Específica Aparente, ABNT NBR NM 52, 2009.

[17] Associação Brasileira de Normas Técnicas, Agregados - Determinação da Composição Granulométrica, ABNT NBR NM 248, 2003.

[18] Associação Brasileira de Normas Técnicas, Agregados para Concreto - Especificação, ABNT NBR 7211, 2009.

[19] Associação Brasileira de Normas Técnicas, Agregados - Determinação do Teor de Argila em Torrões e Materiais Friáveis, ABNT NBR 7218, 2010.

[20] Associação Brasileira de Normas Técnicas, Agregados - Índice de Desempenho de Agregado Miúdo Contendo Impurezas Orgânicas, ABNT NBR 7221, 2012.

[21] A. Wilkinson, "A new method for determination small misorientations from electron back scatter diffraction patterns," Scr. Mater., vol. 44, no. 10, pp. 2379-2385, 2001.

[22] P. S. Bate, R. D. Knutsen, I. Brough, and F. J. Humphreys, "The characterization of low-angle boundaries by EBSD," J. Microsc., vol. 220, no. 1, pp. 36-46, 2005.

[23] Caiuá. http://www.aguasparana.pr.gov.br/pagina-60.html (accessed Dec. 1, 2019).

[24] Mineropar. "Geologia do Paraná. Parque Estadual de Vila Velha." http://www.mineropar.pr.gov.br/arquivos/File/Paineis_geologicos/ParqueEstadualdeVilaVelha_portugues.pdf (accessed Dec. 1, 2019).

[25] L. C. Weinschütz, "Estratigrafia de sequências do grupo Itararé (neocarbonifero-eopermiano) na região de Rio Negro (PR) - Mafra (SC),” Ph.D. dissertation, Univ. Est. Paulista, Rio Claro, 2006.

[26] Serviço Geológico do Brasil. "Geologia: Contexto Geológico Regional." http://www.cprm.gov.br/publique/media/geologia_basica/plgb/curimata/curimata_geologia.pdf (accessed Dec. 1, 2019).

[27] D. C. Miranda et al., "Avaliação do potencial de reatividade álcali-agregado de areias naturais do Estado do Paraná,” in An. $4^{\circ}$ Simp. Parana. Patol. Constr., Curitiba, 2019.

[28] S. Bauer, B. Cornell, D. Figurski, T. Ley, K. Folliard, Alkali-Silica Reaction and Delayed Ettringite Formation in Concrete: A Literature Review. Austin: University of Texas, 2006.

[29] P. J. M. Monteiro, K. Shomglin, H. R. Wenk, and N. P. Hasparyk, "Effect of aggregate deformation on alkali-silica reaction," ACI Mater. J., vol. 98, no. 2, pp. 179-183, 2001.

Author contributions: KFP: conceptualization, methodology, supervision, writing; LEL: conceptualization, supervision, writing; JLB: formal analysis, methodology, writing; DCM: formal analysis, methodology; MOGPB: conceptualization, methodology, supervision, writing; BGD: formal analysis, methodology, writing; NPH: conceptualization, funding acquisition, methodology, supervision, writing; SCK: conceptualization, methodology, supervision, writing.

Editors: Guilherme Aris Parsekian. 